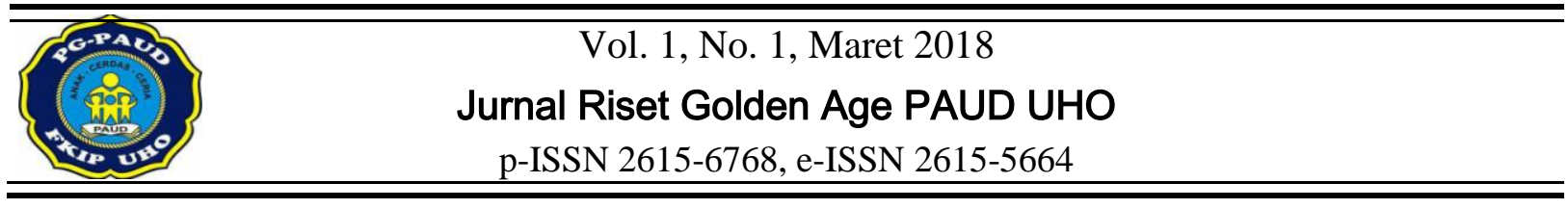

\title{
MENINGKATKAN KEMAMPUAN BERBAHASA ANAK MELALUI METODE BERMAIN PERAN DENGAN TEMA PEKERJAAN DI TK SATU ATAP SD PULAU TAMBAKO KECAMATAN RUMBIA TENGAH
}

\author{
Nasria ${ }^{1)}$, Afifah Nur Hidayah ${ }^{2)}$ \\ ${ }^{1}$ Alumni Jurusan PG-PAUD, Universitas Halu Oleo. Jln. H.E.A Mokodompit, Kendari 93232, \\ Indonesia. \\ ${ }^{2}$ Dosen Jurusan PG-PAUD, Universitas Halu Oleo. Jln. H.E.A Mokodompit, Kendari 93232, \\ Indonesia.
}

\begin{abstract}
Abstrak
Tujuan penelitian ini untuk meningkatkan kemampuan berbahasa anak melalui metode bermain peran dengan tema pekerjaan di TK Satu Atap SD Pulau Tambako Kecamatan Rumbia Tengah. Jenis penelitian ini adalah Penelitian Tindakan Kelas dengan subjek guru dan anak yang berjumlah 23 orang . Penelitian dilakukan dalam dua siklus. Hasil Belajar siswa menunjukkan peningkatan, hal ini dapat dilihat pada kemampuan berbahasa anak dari tes awal sebesar 35\%, meningkatkan pada siklus I menjadi $70 \%$, selanjutnya meningkat pada siklus II menjadi $90 \%$. Kesimpulan penelitian ini yaitu kemampuan berbahasa anak dapat ditingkatkan melalui metode bermain peran dengan tema pekerjaan di TK Satu Atap SD Pulau Tambako Kecamatan Rumbia Tengah.
\end{abstract}

Kata kunci: Kemampuan Berbahasa Anak, Bermain Peran, Pekerjaan.

\section{INCREASES THE CHILDREN'S LANGUAGE SKILLS THROUGH ROLE PLAY METHOD WITH THE THEME OF JOB IN GROUP B TK SATU ATAP SD TAMBAKO ISLAND DISTRICT OF CENTRAL RUMBIA}

\begin{abstract}
This study aimed to improve the children's language skills through role play method with the theme of Job in TK Satu Atap SD Tambako Island District of Central Rumbia. This type of research this is a Classroom Action Research with subject teachers and children that add up to 23 people. The research was conducted in two cycles. Student learning outcome shows an improvement, it can be seen on children's language proficiency from initial tests of 35\%, increase in the cycle I became $70 \%$, subsequently increased in cycle II becomes $90 \%$. Conclusion this study i.e. child language proficiency can be enhanced through role playing with the theme of job in TK Satu Atap SD Tambako Island District of Central Rumbia.
\end{abstract}

Keywords: Children's Language Skills, Role Play, Job

\section{PENDAHULUAN}

Pendidikan nasional berfungsi mengembangkan kemampuan dan membentuk watak serta peradaban bangsa yang bermartabat dalam rangka mencerdaskan kehidupan bangsa, bertujuan untuk berkembangnya potensi peserta didik agar menjadi manusia yang beriman danbertaqwa kepada Tuhan Yang Maha Esa, berakhlak mulia, sehat, berilmu, cakap, kreatif, mandiri, dan menjadi warga Negara yang demokratis serta bertanggung jawab
Sebagaimana yang tercantum dalam Undang-Undang Republik Indonesia No.20 tahun 2003 tentang Sistem Pendidikan Nasional, bahwa: "Pendidikan anak usia dini adalah suatu upaya pembinaan yang ditujukan kepada anak sejak lahir sampai dengan usia enam tahun yang dilakukan melalui pemberian rangsangan pendidikan untuk membantu pertumbuhan dan perkembangan jasmani dan rohani agar anak memiliki kesiapan dalam memasuki pendidikan lebih lanjut". pendidikan informal berbentuk pendidikan keluarga atau pendidikan yang diselenggarakan oleh lingkungan. 
Pendidikan Anak Usia Dini bertujuan mengembangkan seluruh potensi anak agar kelak dapat berfungsi sebagai manusia yang utuh sesuai falsafah suatu bangsa. Anak dapat dipandang sebagai individu yang baru mulai mengenal dunia. Anak-anak belum mengetahui tatakrama, sopan-santun, aturan, norma, etika, dan berbagai hal tentang dunia. Anak-anak belajar berkomunikasi dengan orang lain dan belajar memahami orang lain.

Anak perlu dibimbing agar mampu memahami berbagai hal tentang dunia dan isinya. Anak- anak juga perlu dibimbing agar memahami berbagai fenomena alam dan dapat melakukan keterampilan-keterampilan yang dibutuhkan untuk hidup di masyarakat. Adapun aspek- aspek perkembangan anak usia dini meliputi fisikmotorik, intelektual, moral, emosional, dan bahasa.

Salah satu perkembangan anak yang perlu diperhatikan guru yaitu perkembangan bahasa. Bahasa pada hakikatnya adalah ucapan pikiran dan perasan manusia secara teratur, yang mempergunakan bunyi sebagai alatnya (Depdiknas, 2005: 3). Sedangkan kamus besar Bahasa Indonesia (Alwi, 2002: 88) bahwa bahasa berarti sistem lambang bunyi yang arbitrer, yang digunakan oleh semua orang atau anggota masyarakat untuk bekerjasama, berinteraksi sesama, dan mengidentifikasi diri dalam bentuk percakapan yang baik, tingkah laku yang baik, sopan santun yang baik.

Hurlock (1978: 186) mengatakan perkembangan bahasa anak usia dini ditempuh melalui cara yang sitematis dan berkembang bersama-sama dengan pertambahan usianya. Anak mengalami tahapan perkembangan yang sama namun yang membedakan antara lain: sosial keluarga, kecerdasan, kesehatan, dorongan, hubungan, dengan teman yang turut mempengahurinya, ini berarti lingkungan turut mempengaruhi perkembangan bahasa anak, lingkugan yang baik maka perkembangan anak akan baik, namun sebaliknya jika tidak maka anak juga akan ikut dalam lingkungan tersebut. Hal inilah yang menjadi tolak ukur atau dasar mengapa anak pada umur tertentu sudah dapat berbicara, atau pada umur tertentu belum bisa berbicara.

Aini (2000: 45) mengungkapkan pengembangan kemampuan berbahasa bagi anak usia dini bertujuan agar anak mampu berkomunikasi secara lisan dengan lingkungannya. Lingkungan yang dimaksud adalah lingkungan di sekitar anak antara lain teman sebaya, teman bermain, orang dewasa, baik yang ada di sekolah, di rumah, maupun dengan tetangga di sekitar tempat tinggalnya.

Berdasarkan hasil observasi di TK Satu Atap SD Pulau Tambako, diperoleh informasi bahwa dalam pelaksanaan pembelajaran kemampuan berbahasa anak masih kurang. Hal ini terlihat pada dari kegiatan proses pembelajaran berlangsung sehari-hari yaitu anak sulit berbahasa, cara anak berbahasa masih raguragu dan masih merasa malu untuk bertanya baik pada guru maupun teman sejawatnya. Dalam Penggunaan kosa kata, pengucapan dan pembentukan kalimat juga masih kurang tepat. Disamping itu juga, pembelajaran guru yang masih konvensional. Guru kurang mengaktifkan anak dalam pembelajaran, hanya sebatas bercerita sedangkan pada tahap anak usia dini, pembelajaran harus berfokus pada anak. Anak harus dilibatkan secara langsung dalam pembelajaran. Dari hasil belajar anak menunjukan bahwa, dari 20 anak hanya 8 atau $40 \%$ anak yang memiliki kemampuan berbahasa dengan kriteria Berkembang Baik (BB). Hal ini menunjukan bahwa kemampuan berbahasa anak belum mencapai Kriteria Ketuntasan Minimal (KKM) yang ditetapkan oleh TK Satu Atap SD Pulau Tambako yaitu 75\%. Berdasarkan permasalahan tersebut, maka peneliti berusaha merancang suatu metode pembelajaran yang menarik dan menyenangkan bagi anak untuk meningkatkan kemampuan berbahasa anak melalui metode bermain peran.

Metode pembelajaran bermain peran adalah metode pembelajaran dengan cara anak dilibatkan memerankan tokoh-tokoh atau bendabenda di sekitar anak yang tujuannya mengembangkan daya khayal (imajinasi) dan penghayatan terhadap perkembangan yang dilaksanakan. Drama peran adalah kegiatan spontan dan mandiri di saat anak-anak menguji, menjernihkan dan meningkatkan pemahaman atas diri dan dunianya sendiri. Kegiatan bermain peran di taman kanak-kanak selain fantasi dan emosi yaitu anak belajar berbicara sesuai peran yang dimainkan, belajar mendengarkan dengan baik dan melihat hubungan dari berbagai peran, yang dimainkan bersama.

Manfaat dari pembelajaran bermain peran adalah membantu menyesuaikan diri anak. Dengan memerankan tokoh-tokoh tertentu ia belajar tentang aturan-aturan atau perilaku apa yang bisa diterima orang lain, baik dalam 
berperan sebagai ibu, ayah, guru, murid dan seterusnya. Anak juga belajar untuk memandang suatu masalah dari kacamata tokoh-tokoh yang ia perankan sehingga diharapkan dapat membantu pemahaman sosial pada diri anak

\section{METODE}

Jenis penelitian yang digunakan adalah Penelitian Tindakan Kelas (Classroom Action Research). Ekawarna (2013: 5), menjelaskan bahwa Penelitian Tindakan Kelas adalah penelitian tindakan (action research) yang dilaksanakan oleh guru di dalam kelasnya sendiri. Sedangkan menurut Suyadi (2012: 4), penelitian tindakan kelas merupakan pencermatan yang dilakukan oleh guru di dalam kelasnya sendiri melalui refleksi diri untuk memperbaiki profesinya sebagai guru sehingga hasil belajar anak didik terus meningkat. Lebih lanjut Wibawa dalam Dimyati (2013: 116) menambahkan bahwa penelitian tindakan kelas merupakan penelitian yang mengangkat masalah-masalah aktual yang dihadapi oleh guru di lapangan.

Penelitian ini telah dilaksanakan pada TK satu atap SD Pulau Tambako Kecamatan Rumbia Tengah Kabupaten Bombana pada semester ganjil tahun pelajaran 2015/2016. Subjek dalam penelitian ini adalah guru dan anak didik pada TK satu atap SD Pulau Tambako, Kecamatan Rumbia Tengah yang berjumlah 23 anak.

Adapun faktor-faktor yang diteliti dan diamati dalam penelitian ini adalah sebagai berikut: (a) Faktor anak didik, untuk melihat aktivitas anak dalam mengembangkan kemampuan berbahasa dengan metode bermain peran dan hasil perkembangan anak berupa kemampuan berbahasa, (b) Faktor guru, untuk melihat bagaimana guru menggunakan metode bermain peran dalam upaya mengembangkan kemampuan berbahasa pada TK satu Atap SD Pulau Tambako Kecamatan Rumbia Tengah.

Penelitian ini terdiri dari dua siklus dan masing-masing siklus memuat tiga kali pertemuan. Desain yang telah digunakan dalam penelitian ini adalah desain yang dikemukakan oleh Kemmis dan McTaggart dalam (Ekawarna, 2013: 20) bahwa dalam penelitian tindakan kelas ada empat tahapan yang dilalui, yakni a) Perencanaan, b) Pelaksanaan, c) Observasi dan Evaluasi, serta d) Refleksi.
Kegiatan yang dilakukan pada tahap perencanaan dengan menggunakan media kartu berpasangan pada siklus I, adalah: (a) Membuat skenario pembelajaran berupa rencana kegiatan harian $(\mathrm{RKH})$ untuk siklus I pada pertemuan I sampai dengan pertemuan 3 , yang mengacu pada pengembangan kemampuan bahasa dengan metode bermain peran, (b) Menyiapkan naskah, alat, media dan kostum yang akan digunakan dalam kegiatan bermain peran, (c) Membuat lembar observasi aktivitas guru dalam proses belajar mengajar sebagai acuan untuk melihat keterlaksanaan proses pembelajaran sesuai dengan yang direncanakan.

Tahap pelaksanaan tindakan meliputi: (a) Guru menerangkan teknik bermain peran dengan cara yang sederhana dan memberikan contoh kepada anak didik, (b) Guru memberi kebebasan bagi anak untuk memilih peran yang disukainya. Guru memberi kesempatan kepada anak untuk memilih peran yang disukainya kemudian dibentuk kelompok sesuai dengan peran yang telah dipilih, (c) Guru memberi bimbingan kepada anak bagaimana anak memerankan peran yang mereka pilih, (d) Guru menetapkan dengan jelas masalah dan peran yang mereka harus mainkan, (e) Posisi anak didik diatur dengan rapi di dalam kelas agar bisa mengamati dan mengikuti kegiatan pembelajaran dengan baik.

Kegiatan observasi dilakukan setiap kali pertemuan selama pelaksanaan tindakan dalam proses pembelajaran dengan menggunakan lembar observasi yang telah disiapkan. Pada tahap ini dilaksanakan pengamatan secara seksama mengenai aktivitas anak didik selama mengikuti proses pembelajaran.

Tahap refleksi, guru melaksanakan refleksi berdasarkan hasil yang didapatkan dalam tahap observasi dan evaluasi untuk melihat apakah kegiatan yang dilaksanakan telah memenuhi target sesuai dengan kriteria indikator kinerja.

Adapun kegiatan yang dilakukan pada tahap perencanaan dengan menggunakan media kartu berpasangan pada siklus II, adalah: (a) Membuat skenario pembelajaran berupa rencana kegiatan harian (RKH) untuk siklus II pada pertemuan I sampai dengan pertemuan III, yang mengacu pada upaya mengembangkan kemampuan berbahasa dengan metode bermain peran, (b) Menyiapkan naskah, alat, media dan kostum yang akan digunakan dalam kegiatan bermain peran, (c) Membuat lembar observasi aktivitas guru dalam proses pembelajaran 
sebagai acuan untuk melihat sejauhmana keterlaksanaan proses pembelajaran sesuai dengan yang direncanakan, (d) Membuat lembar observasi aktivitas anak didik selama proses pembelajaran dengan menggunakan metode bermain peran, (e) Menyediakan alat evaluasi untuk melihat peningkatan kemampuan berbahasa dengan metode bermain peran.

Tahap pelaksanaan tindakan meliputi: (a) Guru menerangkan teknik bermain peran dengan cara yang sederhana, (b) Guru memberi kebebasan bagi anak untuk memilih peran yang disukainya, (e) Guru menjelaskan masalah dan peranan yang mereka harus mainkan, (f) Posisi anak didik diatur dengan rapi di dalam kelas agar bisa mengamati dan mengikuti kegiatan pembelajaran dengan baik, (g) Setelah posisi anak didik diatur sesuai dengan yang diharapkan, guru memulai kegiatan pembelajaran dengan metode bermain peran.

Tahap observasi dilaksanakan pengamatan secara seksama mengenai aktivitas anak didik selama mengikuti proses pembelajaran. Observasi dilakukan juga terhadap guru untuk melihat sejauhmana keterlaksanaan proses pembelajaran dengan menggunakan metode bermain peran. Pada pelaksanaan observasi, peneliti berkolaborasi dengan guru TK satu atap SD Pulau Tambako Kecamatan Rumbia Tengah.

Pada tahap refleksi, guru melaksanakan tukar pikiran berdasarkan hasil yang didapatkan dalam tahap observasi dan evaluasi siklus I untuk melihat apakah kegiatan yang dilaksanakan telah memenuhi target sesuai dengan kriteria indikator kinerja.

Data yang diperoleh dari penelitian ini adalah data kualitatif dan data kuantitatif. Data kualitatif digunakan untuk menghimpun data tentang pelaksanaan proses pembelajaran yang dilaksanakan oleh guru. Data kualitatif diperoleh melalui lembar observasi. Sedangkan data kuantitatif diperoleh melalui lembar instrumen/evaluasi yang dilakukan pada setiap pertemuan dan diakhir siklus tindakan.

Data dalam penelitian ini dihimpun melalui hasil wawancara, observasi dan dokumentasi. Wawancara dilakukan pada pertemuan langsung yang direncanakan antara pewawancara dan yang diwawancarai untuk saling bertukar pikiran, guna memberikan atau menerima informasi tertentu yang diperlukan dalam penelitian (Sukardi, 2013: 49). Dalam penelitian ini, yang diwawancarai adalah guru
TK satu atap SD Pulau Tambako Kecamat Rumbia Tengah. Observasi dilakukan oleh guru TK satu atap SD Pulau Tambako sebagai observer dengan menggunakan lembar observasi. Penggunaan lembar observasi digunakan untuk melihat proses pelaksanaan pembelajaran yang dilaksanakan oleh peneliti ketika menggunakan metode bermain peran.

Teknik analisis data yang digunakan dalam penelitian ini berupa analisis deskriptif yang dimaksudkan untuk memberikan gambaran mengenai kemampuan berbahasa anak melalui metode bermain peran. Dalam menganalisis data dan memberi penilaian pada setiap indikator kinerja, peneliti mengacu pada pedoman pemberian penilaian dalam satuan pendidikan di taman kanak-kanak, yaitu dengan penilaian secara kualitatif atau dengan memberikan nilai dalam bentuk simbol bintang seperti: * = Belum Berkembang (BB), $* *=$ Mulai Berkembang $(\mathrm{MB}), * * *=$ Berkembang Sesuai Harapan $(\mathrm{BSH})$, dan $* * * *=$ Berkembang Sangan Baik (BSB) (Depdiknas, 2004:26).

\section{HASIL DAN PEMBAHASAN}

Sebelum kegiatan penelitian ini dilaksanakan, peneliti terlebih dahulu melakukan pertemuan awal dengan kepala TK satu atap SD Pulau Tambako Kecamatan Rumbia Tengah. Pertemuan ini bermaksud untuk menyampaikan tujuan dari peneliti yaitu mengadakan penelitian di TK satu atap SD Pulau Tambako Kecamatan Rumbia Tengah. Selanjutnya, kepala taman kanak-kanak mengarahkan peneliti untuk berdiskusi dengan guru Kelompok B, kemudian peneliti melakukan observasi awal di TK satu atap SD Pulau Tambako Kecamatan Rumbia Tengah khususnya Kelompok B

Peneliti melalukakan wawancara singkat dengan guru kelompok B di taman kanak-kanak tersebut. Berdasarkan hasil observasi dan wawancara yang dilakukan peneliti, ditemukan bahwa kemampuan berbahasa anak pada kelompok B TK satu atap SD Pulau Tambako Kecamatan Rumbia Tengah masih rendah yaitu berada pada taraf Mulai Berkembang atau dengan simbol bintang $(* *)$.

Pelaksanaan tindakan siklus I, peneliti melaksanakan pembelajaran sesuai denga Rencana Kegiatan Harian (RKH) yang telah disiapkan terlebih dahulu dengan tema pekerjaan yang dilaksanakan pada tanggal 3, 4, dan 5 Agustus 2015. Tindakan penelitian dilaksanakan 
di ruang kelompok B TK satu atap SD Pulau Tambako Kecamatan Rumbia Tengah, anak telah siap belajar dengan guru yaitu meningkatkan kemampuan berbahasa melalui metode bermain peran. Selanjutnya peneliti berkolaborasi dengan guru untuk melaksanakan tindakan yang sudah direncanakan.

Pertemuan I siklus I dilaksanakan dengan tema pekerjaan, subtema tukang kayu. Jumlah anak yang mengikuti pembelajaran sebanyak 20 anak. Indikator yang akan dicapai adalah Pengembangan Kosa Kata, Kelancaran Berbahasa Anak, Berbahasa dengan menggunakan artikulasi dengan jelas, dan berbahasa dengan kalimat lengkap. Pada pelaksanaan pembelajaran peneliti sebagai guru melaksanakan pembelajaran sesuai dengan RKH I. Sebelum melaksanakan pembelajaran, guru menyiapkan anak untuk belajar dengan mengucapkan salam. Setelah itu guru meminta salah satu anak didik untuk memimpin doa belajar yang dituntun oleh guru. Selanjutnya, guru menyiapkan naskah, alat, media dan kostum yang akan digunakan dalam kegiatan bermain peran.

Observasi dilakukan untuk melihat pelaksanaan pembelajaran dengan meningkatkan kemampuan berbahasa melalui metode bermain peran sesuai dengan Rencana Kegiatan Harian (RKH) yang telah dibuat. Observasi dilakukan oleh guru TK selaku observer terhadap aktivitas mengajar yang dilakukan oleh peneliti selaku guru dan aktivitas belajar siswa, dengan lembar observasi yang telah disiapkan oleh peneliti.

Siklus I diperoleh persentase ketercapaian sebesar $62,50 \%$, sedangkan aktivitas belajar anak didik diperoleh persentase ketercapaian sebesar $68,75 \%$. Pada siklus II, persentase ketercapaian aktivitas mengajar guru mengalami peningkatan menjadi 93,75\%, sedangkan persentase ketercapaian aktivitas belajar anak didik juga mengalami peningkatan menjadi $87,50 \%$. Sehingga proses pembelajaran dihentikan pada siklus II.

Hasil belajar siswa menunjukkan peningkatan, hal ini dapat dilihat pada kemampuan berbahasa anak dari tes awal sebesar 35\%, meningkatkan pada siklus I menjadi $70 \%$, selanjutnya meningkat pada siklus II menjadi $90 \%$.

\section{KESIMPULAN DAN SARAN}

Berdasarkan hasil dan pembahasan penelitian ini disimpulkan bahwa kemampuan berbahasa anak dapat ditingkatkan melalui metode bermain peran dengan tema pekerjaan di TK Satu Atap SD Pulau Tambako Kecamatan Rumbia Tengah.

Saran yang dapat dikemukakan dari hasil penelitian ini yaitu diharapkan kepada guru, dalam pelaksanaan pembelajaran hendaknya mempertimbangkan materi, media, dan strategi yang tepat untuk anak didik dan guru dituntut untuk selalu kreatif dan inovatif dalam melaksanakan kegiatan-kegiatan yang dapat meningkatkan potensi anak didik.

\section{DAFTAR PUSTAKA}

Aini, Siti. 2000. Bahasa dalam Pengajaran. Bandung: ITB.

Alwi, Hasan. 2002. Kamus Besar Bahasa Indonesia. Jakarta: Balai Pustaka.

Depdiknas. 2004. Pedoman Penilaian di Taman Kanak-Kanak. Jakarta: Depdiknas.

2005. Kurikulum 2004. Jakarta: Departemen Pendidikan Nsional Direktorat Jenderal Pendidikan Dasar dan Menengah.

Dimyati, Johni. 2013. Metodologi Penelitian Pendidikan dan Aplikasinya pada Pendidikan Anak Usia Dini (PAUD). Jakarta: Kencana.

Ekawarna. 2013. Penelitian Tindakan Kelas. Edisi Revisi. Jakarta: Referensi.

Hurlock, Elizabeth. 1978. Perkembangan Anak. Erlangga : Jakarta.

Suyadi. 2012. Buku Panduan Guru Profesional: Penelitian Tindakan Kelas (PTK) dan Penelitian Tindakan Sekolah (PTS). Yogyakarta: Andi

Undang-Undang Nomor 20 Tahun 2003 tentang Sistem Pendidikan Nasional. Jakarta: Sinar Grafika. 